\title{
Glucose-6-phosphate dehydrogenase activity in erythrocytes of experimental animals
}

\author{
LAI HUNG CHEUN \\ From the Department of Pathology and Bacteriology, \\ University of Hong Kong, Hong Kong
}

SYNOPSIS Guinea-pigs, rats, dogs, rabbits, monkeys, sheep, and goats were screened for G-6PD $\overrightarrow{0}$ activity in erythrocytes by the methaemoglobin reduction test, the brilliant cresyl blue decolorization $\%$ test, and the spectrophotometric determination of the NADPH generation rate. Guinea-pigs, rats, $\frac{\rho}{A}$ dogs, rabbits, and monkeys were found to have normal G-6PD activity in erythrocytes, whereaso

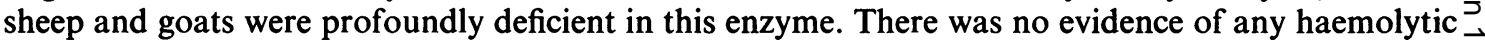
anaemia in sheep and goats at the time of study. The relative sensitivity of these tests is discussed. $z$

Glucose-6-phosphate dehydrogenase (G-6PD) is the first enzyme in the pentose phosphate pathway of glucose metabolism, catalysing the oxidation of glucose-6-phosphate (G-6P) to 6-phosphogluconate (6-PG) with the concomittent formation of reduced nicotinamide adenine dinucleotide phosphate (NADPH) from the coenzyme nicotinamide adenine dinucleotide phosphate (NADP). An inherited deficiency of this enzyme in the erythrocytes has been demonstrated during recent years, with various frequencies in different racial and ethnic groups. The affected individuals are liable to develop haemolysis after the ingestion of certain drugs and fava beans.

For a very long time severe jaundice has been known to occur in certain animals following the ingestion of poisonous plants. Tribulus terrestris and Lippia rehmani were reported to be responsible for the disease tribulosis, geel-dik-kop or yellow-thickhead of sheep in South Africa; Narthercium ossifragium for the disease yellowses or head-grit of sheep in Great Britain, and Lantanna camara for jaundice, without marked destruction of liver tissue, in animals over widespread geographical distributions (Turbet, 1928; Quin, 1928, 1933; Rimington and Quin, 1935; Steyn and Van der Walt, 1941; Hurst, 1942; Greig, 1943; Louw, 1943, cited by Heikel, Knight, and Rimington, 1960). Brown (1963) reported that there is a close resemblance between the clinical appearances of Geel-dik-kop and enzootic icterus of sheep in South Africa and those of the drug-induced type of haemolytic anaemia due to deficiency of G-6PD in human subjects. He further pointed out that the inability of ovine red cells to reduce methaemoglobin as efficiently as normal human red cells might be a pathogenic factor in the above diseases. Kaneko and Smith (1964) showed $\overrightarrow{0}$ that in general ovine red cells have a much lowero G-6PD activity and a lesser capacity to reduce methaemoglobin than those of normal human redo cells. The acclimatization of sheep to high altitude for some considerable time did not significantly raise the erythrocyte G-6PD level.

A review of the literature shows that this red cello enzyme has been little studied in other animals. Therefore an attempt has been made to compare the activity of G-6PD in erythrocyte in various experimental animals.

MATERIAL AND METHOD

Five adult animals of each of the species, guinea-pig, albino rat, dog, rabbit, cynomolgus monkey, sheep, and $\frac{0}{3}$ goat were studied. Five $\mathrm{ml}$. of blood was taken from each animal either by venous or cardiac puncture. Heparin was $\triangle$ used as anticoagulant and inosine was added, to give a $D$ concentration of $4 \mathrm{mg}$. per ml. of blood, to prevent the premature inactivation of enzymes. The samples were $N$ stored at $4^{\circ} \mathrm{C}$, immediately after collection and were. assayed within 24 hours.

A methaemoglobin reduction test (Brewer, Tarlov, and Alving, 1962), with the slight modification of reducing the $\omega$ volume of reagents and blood to one-fourth of that in the original method, was used for screening the activity of G-6PD in erythrocytes. Cells showing complete reduction $\mathbb{E}$ of the methaemoglobin within three hours' incubation? were considered to be normal in regard to this enzyme, $T$ whereas those showing no reduction after incubation? were recorded as positive. The results of this test were then checked by the brilliant cresyl blue decolorization $\mathbb{D}$ test (Motulsky and Campbelle-Kraut, 1961) using the 
reagent kits supplied by the Sigma Company. Failure to decolorize the brilliant cresyl blue after three hours' incubation was recorded as positive.

Actual measurement of erythrocyte G-6PD activities was carried out in each animal by a modified Hornberg and Horecker's spectrophotometric assay of the NADPH generation rate (Prankard, 1962). The absorbancy of the NADPH was measured by a Beckman DU spectrophotometer at a wave length of $340 \mathrm{~m} \mu$ using a $1 \mathrm{~cm}$. quartz cuvette. Optical density readings were made at oneminute intervals over a period of 10 minutes and plotted on graph paper. A linear segment, including at least five consecutive readings, was selected for calculation of the mean increment in optical density per minute. Enzymatic activities were expressed as units of changes in optical density per minute per gram of haemoglobin (U.O.D. 340 $\mathrm{m} \mu / \mathrm{min} . / \mathrm{g}$. haemoglobin).

In the sheep and goats the haemoglobin content of the blood was determined by the cyanmethaemoglobin method and the total serum bilirubin estimated by the diazo method of King and Coxon (1950). The total and differential white cell counts, the platelet count, the packed cell volume, and the reticulocyte count were carried out by the standard methods.

\section{RESULTS}

The results on the screening tests and the actual measurement of G-6PD activities in the various experimental animals are shown in Figure 1. Blood samples taken from guinea-pigs, rats, dogs, rabbits, and monkeys were all capable of reducing methaemoglobin completely after incubation with methylene blue at $37^{\circ} \mathrm{C}$. for three hours. The mean erythrocyte G-6PD activities of these animals were $9 \cdot 44 \pm 1 \cdot 18$; $13.82 \pm 1 \cdot 19 ; 11.0 \pm 2 \cdot 70 ; 11.86 \pm 1.52$ and $10.6 \pm$ 3.79 U.O.D. $340 \mathrm{~m} \mu / \mathrm{min} . / \mathrm{g}$. haemoglobin respectively. On the contrary, blood samples taken from all five sheep and all five goats were incapable of reducing methaemoglobin and also failed to decolorize the brilliant cresyl blue in the dye decolorization test. Their mean erythrocyte G-6PD activities were $1.20 \pm 0.37$ and $1.98 \pm 0.27$ U.O.D. 340 $\mathrm{m} \mu / \mathrm{min} . / \mathrm{g}$. haemoglobin respectively.

The appropriate laboratory investigations excluded a haemolytic anaemia in the sheep and goats. The haemoglobin content ranged from 10.4 to $16.2 \mathrm{~g}$. per $100 \mathrm{ml}$.; the reticulocyte counts were under $1 \%$; the total serum bilirubin levels were not more than $1 \mathrm{mg} . \%$ per $100 \mathrm{ml}$; ; and the total and differential white cell count, the P.C.V., M.C.H.C., and red cell morphology were all within the normal limits.

\section{DISCUSSION}

Two methods are currently used for screening G-6PD activity in erythrocytes, namely, the methaemoglobin reduction test and the brilliant cresyl blue decolorization test. The former is simpler and much

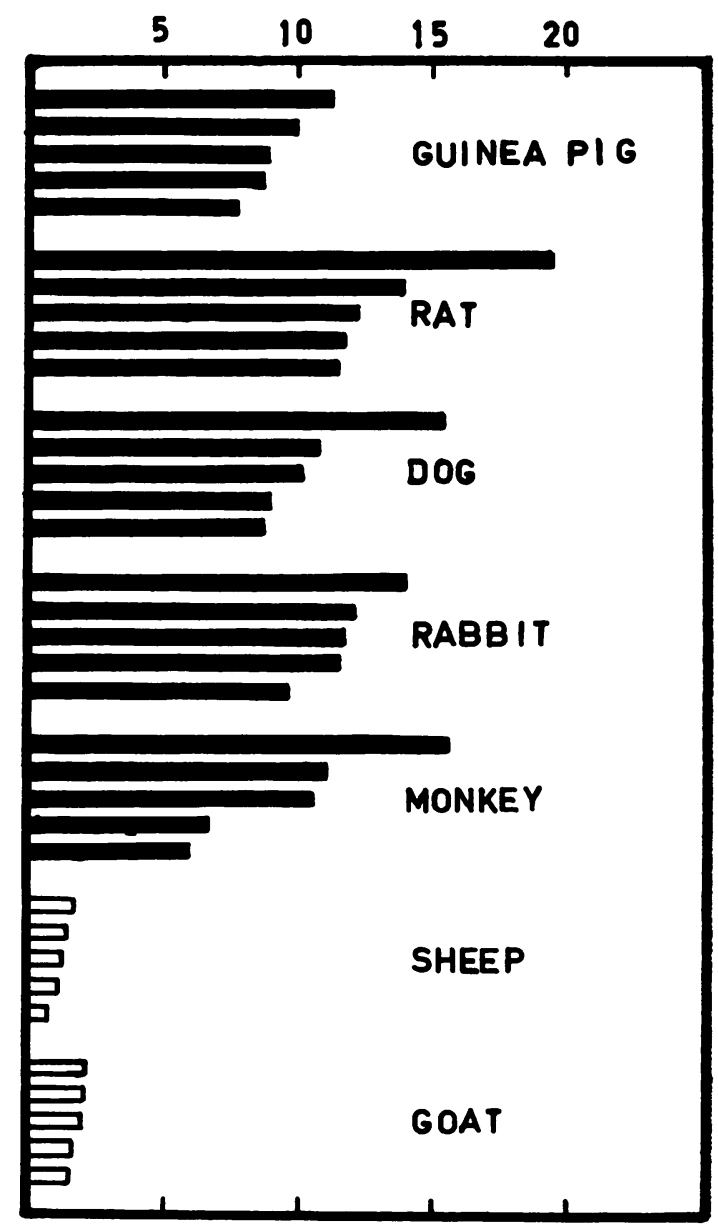

FIG. 1. Activity of G-6PD in erythrocytes of experimental animals (U.O.D. $340 \mathrm{m \mu} / \mathrm{min}$./g. haemoglobin). The white columns indicate that the cells are incapable of reducing methaemoglobin in the methaemoglobin reduction test.

less expensive and thus lends itself to massive screening work. Brewer et al. (1962) pointed out, however, that erroneous results may be given by the methaemoglobin reduction test if the blood samples are haemolysed, clotted, or profoundly anaemic. In the brilliant cresyl blue decolorization test both G-6P and NADP are essential ingredients and any anaemia should be corrected by adjusting the amount of blood used in the test. In the methaemoglobin reduction test, neither the substrate G-6P nor the coenzyme need be added to the assay system from external sources. Exhaustion of either G-6P, or N.A.D.P., or both, from any cause, without concurrent inactivation of G-6PD in the sample, will give false positive results in the methaemoglobin reduction test but not in the brilliant cresyl blue decolorization test. 
Furthermore, in the methaemoglobin reduction test an enzyme known as NADPH-dependent methaemoglobin reductase is required to indicate the activity of G-6PD. The NADPH formed during the oxidation of G-6P reduces the methylene blue which in turn will restore the methaemoglobin to haemoglobin (Fig. 2).

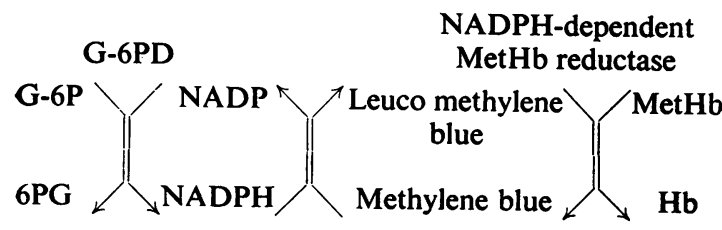

FIG. 2. The methaemoglobin reduction test.

It is possible that a defect in the action of this reductase, although this has not been reported in the human being, could give results similar to that of G-6PD deficiency, with a failure to reduce the methaemoglobin in the methaemoglobin reduction test. The spectrophotometric measurement of the G-6PD activity will assist in differentiating these two conditions; in G-6PD deficiency the NADPH generation rate will be inhibited while in a deficiency of NADPH-dependent methaemoglobin reductase it will not. Accordingly all three methods were used in combination in the present study. It was accepted that there was a genuine deficiency of G-6PD if positive results were obtained in both the qualitative tests. These were confirmed by the quantitative measurement.

The results show that guinea-pigs, rats, dogs, rabbits, and monkeys have a normal G-6PD activity in the red cells. On the other hand, sheep and goats, taxonomically closely-related animals, appear to be profoundly deficient in this enzyme: nevertheless $\overrightarrow{\bar{S}}$ they did not show evidence of any haemolyticprocess. Thus this deficiency is somewhat similar to 등 that found abnormally in certain human beings. $\frac{\bar{\rho}}{\bar{s}}$ Here, as with the sheep and goats, it is not associated $\bar{\nabla}$ with any stigmata and is not apparent until the cells $\frac{\circ}{0}$ are challenged with the offensive agents when $a^{\mathrm{s}}$ haemolytic process occurs.

These findings suggest that sheep and goats may $\overrightarrow{\vec{H}}$ be ideal animals for the experimental investigation ${ }_{\sigma}^{\omega}$ of the drug-induced type of haemolytic anaemia and $\bar{?}$ favism. They may be useful for screening drugs? which might induce haemolytic episodes in G-6PD- 6 deficient human subjects or as positive control for the study of the comparative sensitivity of various $\frac{\vec{A}}{A}$ G-6PD assay techniques.

I wish to thank Professor J. B. Gibson, Head of the Department of Pathology and Bacteriology, University of $\AA$ Hong Kong, and Dr. J. Grant for their invaluable advice; Dr. W. K. Cheung and Dr. W. C. Chan for their supply of monkeys' blood; Mr. P. Y. Chiu and Mr. K. K. Wei for their technical assistance.

\section{REFERENCES}

Brewer, G. J., Tarlov, A. R., and Alving, A. S. (1962). J. Amer. Med. Ass., 180, 386.

Brown, J. M. M. (1963). Ann. N.Y. Acad. Sci., 104, 504.

Heikel, T., Knight, B. C., and Rimington, C. (1960). Proc. Roy. Soc. B, $153,47$.

Kaneko, J. J., and Smith, J. Z. (1964). Amer. J. vet. Res., 25, 846.

King, E. J., and Coxon, V. J. (1950). J. clin. Path., 3, 248. Proceedings of the Conference on Genetic Polymorphisms and Geographic Variations in Diseases, edited by B. Blumberg, p. 159, Grune and Stratton, New York.

Prankard, T. A. J. (1962). Association of Clinical Pathologists. 